\title{
Note \\ IN VITRO CULTURE FROM MATURE SEEDS OF PASSIFLORA SPECIES
}

\author{
Flavia Guzzo; Stefania Ceoldo; Filippo Andreetta; Marisa Levi* \\ Università di Verona - Dipartimento Scientifico e Tecnologico, Strada le Grazie 15 - 37134 Verona - Italy. \\ *Corresponding author <marisa.levi@univr.it>
}

\begin{abstract}
The genus Passiflora comprises hundred species, mainly native of the South American tropics and rainforests, which are grouped into 21 subgenera. Some species are widely studied for their economic importance and are chiefly cultivated for production of fruit juice. To obtain a continuous source of material for a screening of secondary metabolites, zygotic embryo culture was attempted for 62 Passiflora species, starting from seeds mainly collected in the wild. Twenty nine of these species produced calli, which had very different growth rates. Plants were successfully regenerated from calli of 13 different species. For 25 of the responsive species this is the first report of in vitro culture.

Key words: Passiflora regeneration, embryo culture, endosperm culture, ethnobotanical species, plant acclimatization
\end{abstract}

\section{REGENERAÇÃO E CULTURA IN VITRO DE ESPÉCIES DE PASSIFLORA}

\begin{abstract}
RESUMO: O gênero Passiflora compõe centenas de espécies, a maioria de origem dos trópicos e das florestas da América do Sul, as quais são agrupadas em 21 subgêneros. Algumas espécies foram intensamente estudadas por sua importância econômica e são cultivadas principalmente para a produção de suco de fruta. Cultura de 29 espécies de Passiflora foram obtidos a partir de embriões zigóticos e de culturas de endosperma. Foram obtidos diferentes tipos de calos de crescimento, de tal forma que plantas foram regeneradas a partir de calos de 13 espécies diferentes. Não haviam sido ainda relatadas culturas in vitro para 25 das espécies trabalhadas.

Palavras-chave: cultura de embrião, cultura de endosperma, espécies etnibotânicas, regeneração, aclimatização
\end{abstract}

\section{INTRODUCTION}

The genus Passiflora comprises several hundred species, mainly native of the South American tropics and rainforests, which are grouped into 21 subgenera. Some species (P. edulis, P. quadrangularis, P. ligularis) are widely studied for their economic importance and are chiefly cultivated for production of fruit juice. $P$. incarnata is reputed for its sedative properties and several other species are known for their ethnobotanical uses (see The Phytochemical and Ethnobotanical Databases, http://www.ars-grin.gov/duke/). However, the molecules responsible for these various activities are known only for a few species. Also, some Passiflora species have been described only recently (e.g. P. trialata, Feuillet \& MacDougal, 1996).

For systematic study of the activities of secondary metabolites, a continuous source of material is necessary. For some Passiflora species, dehydrated seeds can be purchased, but for most, seeds have to be collected in the wild. Nonetheless, dehydrated seeds of many Passiflora species may require from many months up to two years to germinate (Vanderplank, Passiflora Society International Meeting, Rome, 15-16 September 2001). To alleviate these difficulties, an in vitro collection of Passiflora species, together with a greenhouse collection of regenerated plants was established.

Many in vitro culture techniques have been described for the Passiflora genus including regeneration from hypocotyl, leaves and cotyledons (Faria \& Segura, 1997; Dornelas \& Vieira, 1994), regeneration from leaf disks (Monteiro et al., 2000) and mesophyll and cotyledon-derived protoplasts (Dornelas \& Vieira, 1993; Vaz d'Utra et al., 1993; Otoni et al., 1995, Anthony et al., 1999), regeneration after protoplast fusion (Dornelas et al., 1995), and micropropagation (Kawata et al., 1995). A mature endosperm culture has been reported for P. foetida (Mohamed et al., 1996). Embryo and endosperm culture from seeds of several Passiflora species mainly collected in the wild has been attempted in this study. 


\section{MATERIAL AND METHODS}

Passiflora seeds, collected in the wild or produced in greenhouse, were kindly furnished by Dr. Maurizio Vecchia (Ripalta Cremasca, Cremona, Italy). For each species, four to 20 seeds were available. Mature seeds were surface sterilized with $70 \%$ ethanol for $10 \mathrm{~min}$, followed by immersion in a sodium hypochlorite solution, containing 5\% active chlorine for $70 \mathrm{~min}$. During the first $10 \mathrm{~min}$, samples were kept under vacuum. Seeds were extensively washed with sterile water, soaked overnight at $35^{\circ} \mathrm{C}$, and then for $24 \mathrm{~h}$ at room temperature. They were then treated with sodium hypochlorite for $10 \mathrm{~min}$ and extensively washed prior to dissection. Embryos were extracted from seeds under a dissection microscope in a flow cabinet, and placed on media $\mathrm{A}$ and $\mathrm{B}$; for some species, $\mathrm{C}$ or $\mathrm{BG}$ medium was also used (for media composition see Table 1). When solid parts of endosperm were present, they were explanted as well.

The following treatments depended on the response of the embryo: a) when embryo produced calli, these were maintained on B5+ or B5-2 medium (Table 1) depending on the species, and subcultured every 30 days; part of these calli were transferred to regenerating medium (REM) to regenerate shoots; rooting medium (RM) was used to obtain roots from shoots; b) when germination from explanted embryos occurred, part of the plantlets where cut into pieces and transferred to B5-2 medium to obtain undifferentiated calli, which were treated as above.

Part of the regenerated or germinated plantlets were transferred into Magenta vessels and grown in vitro in hormone-free MS medium (Murashige \& Skoog, 1962) until both shoots and roots were well developed. The small plants were acclimatized in autoclave-sterilized soil for about three weeks at $100 \%$ humidity, and then transplanted into pots in a greenhouse.

\section{RESULTS AND DISCUSSION}

\section{Embryo and endosperm culture: early events}

Seeds of Passiflora genus vary greatly in size and shape. However, several common features are apparent, including hard seed coats surrounding a white, well-developed, straight embryo, with large flat cotyledons. A thin layer of endosperm, which can be ruminated, surrounds the embryo.

Endosperm and embryos extracted from seeds (Table 2) were grown in two different media, A and B (Table 1). The plant growth regulator and sucrose concentration of these media have been reported to induce undifferentiated callus formation (medium A) and to stimulate in vitro germination of zygotic embryos (medium B) in rice (Ko et al., 1983). Twenty six species responded to either A or B medium with embryo germination or callus formation (Table 2).

When a sufficient number of seeds were available, embryos of species that did not respond to A or B media were treated with medium containing gibberellic acid (BG medium, Table 2). Embryos of $P$. mayarum, $P$. morifolia and $P$. subpeltata germinated on this medium. $P$. foetida and P. palmeri were also tested in medium C, which induced embryo germination $(P$. foetida) and callus production from embryos (P. palmeri).

In most of the responsive species, the earlier modification observed in responding embryos was cotyledon greening, which occurred within one-three weeks of culture (data not shown), followed by cotyledon enlargement and opening (Figure 1a). This effect was independent of the composition of the growth medium.

The subsequent events depended on the final fate of the embryos: germinating embryos presented further cotyledon and root expansion (Figures 1a, b), occasionally accompanied by a small callus proliferation, especially at the hypocotyl-root border (Figure 1a), and cotyledon edges. Another group of embryos showed the on-

Table 1 - Media used for Passiflora culture

\begin{tabular}{|c|c|c|c|c|c|c|c|c|c|c|}
\hline Medium & Salts, vitamins & Sucrose & $2,4-\mathrm{D}$ & Kinetin & NAA & GA & $6 \mathrm{BAP}$ & IAA & IBA & Agar \\
\hline & & $\%$ & ----- & ------- & ------ & mol I & ----- & ---- & ----- & $\%$ \\
\hline A & MS & 3 & 13.6 & 9.3 & - & - & - & - & - & 0.9 \\
\hline B & MS & 6 & - & 0.93 & 1.0 & - & - & - & - & 0.9 \\
\hline BG & MS & 6 & - & 0.93 & 1.0 & 1.0 & - & - & - & 0.9 \\
\hline $\mathrm{C}$ & MS & 2 & 2.25 & - & - & - & 1.1 & 1.4 & - & 0.8 \\
\hline REM & MS & 2 & 2.25 & - & - & - & 1.1 & - & 2.46 & 0.8 \\
\hline RM & MS & 2 & - & - & - & - & - & - & 2.46 & 0.8 \\
\hline B5+ & B5 & 2 & 2.25 & - & - & - & - & - & - & 0.8 \\
\hline B5-2 & B5 & 2 & 9.0 & - & - & - & - & - & - & 0.8 \\
\hline
\end{tabular}

REM: regeneration medium; RM: rooting medium; MS: Murashige and Skoog's medium (Murashige \& Skoog, 1962); B5: Gamborg's medium (Gamborg et al., 1968); 2.4-D: 2.4-dichlorophenoxyacetic acid; NAA: naphtalenacetic acid; GA: gibberellic acid; 6BAP: 6benzylaminopurine; IAA: indoleacetic acid; IBA: indole-3-butyric acid. 
Table 2 - Type of response of Passiflora species to different inducing media

\begin{tabular}{|c|c|c|c|c|c|}
\hline \multirow{2}{*}{ Passiflora responsive species (subgenus) } & \multicolumn{4}{|c|}{ Medium } & \multirow[t]{2}{*}{ Regeneration } \\
\hline & A & $\mathrm{B}$ & $\mathrm{C}$ & BG & \\
\hline *P.apetala (Decaloba) & $\mathrm{EG}, \mathrm{CFE}$ & EG & $\mathrm{nt}$ & nt & - \\
\hline *P.auriculata (Decaloba) & CFEM & CFEM & nt & nt & - \\
\hline *P.candida (Astrophea) & EG, CFEM & - & nt & nt & - \\
\hline P.cincinnata (Passiflora) & CFE, CFEM & EG & $\mathrm{nt}$ & $\mathrm{nt}$ & $+(\mathrm{A}, \mathrm{B})$ \\
\hline *P.cirrhiflora (Polyanthea) & CFEM & EG, CFEM & $\mathrm{nt}$ & $\mathrm{nt}$ & - \\
\hline P.coccinea (Distephana) & CFEM & - & $\mathrm{nt}$ & $\mathrm{nt}$ & - \\
\hline *P.coriacea (Decaloba) & EG, CFEM & EG & nt & nt & $+(\mathrm{A})$ \\
\hline *P.crenata (Passiflora) & - & EG & nt & nt & - \\
\hline P.foetida (Dysosmia) & - & EG & EG & nt & $+(\mathrm{C})$ \\
\hline *P.garckei (Passiflora) & - & CFEM & $\mathrm{nt}$ & nt & $+(\mathrm{B})$ \\
\hline *P.glandulosa (Distephana) & CFE & EG, CFEM & $\mathrm{nt}$ & $\mathrm{nt}$ & $+(\mathrm{B})$ \\
\hline *P.mansii (Astrophea) & CFE & EG & nt & $\mathrm{nt}$ & - \\
\hline P.incarnata (Passiflora) & CFEM, CFE & CFEM & $\mathrm{nt}$ & $\mathrm{nt}$ & $+(\mathrm{A})$ \\
\hline P.incarnata "alba" (Passiflora) & EG, CFEM & EG & nt & nt & $+(\mathrm{A})$ \\
\hline *P.kawensis (Astrophea) & EG & - & $\mathrm{nt}$ & nt & - \\
\hline *P.mayarum (Passiflora) & - & - & $\mathrm{nt}$ & EG & $+(\mathrm{BG})$ \\
\hline *P.morifolia (Decaloba) & - & - & $\mathrm{nt}$ & $\mathrm{EG}, \mathrm{CFE}$ & nt \\
\hline *P.naviculata (Passiflora) & - & EG & $\mathrm{nt}$ & nt & - \\
\hline *P.nitida (Passiflora) & CFE, CFEM & EG,CFE & $\mathrm{nt}$ & $\mathrm{nt}$ & - \\
\hline *P.organensis (Decaloba) & - & EG & nt & nt & - \\
\hline *P.palmeri (Dysosmia) & CFEM & - & EG, CFEM & nt & $+(\mathrm{C})$ \\
\hline *P.platyloba (Passiflora) & - & EG & nt & nt & nt \\
\hline *P.rufa (Decaloba) & CFEM & - & $\mathrm{nt}$ & $\mathrm{nt}$ & $\mathrm{nt}$ \\
\hline *P.sicyoides (Decaloba) & - & EG & nt & nt & - \\
\hline *P.subpeltata (Passiflora) & - & - & $\mathrm{nt}$ & EG & $+(\mathrm{BG})$ \\
\hline *P.subrotunda (Passiflora) & $\mathrm{EG}, \mathrm{CFE}$ & CFE & nt & nt & - \\
\hline *P.tenuifila (Passiflora) & CFEM & EG, CFEM & nt & nt & $+(\mathrm{B})$ \\
\hline *P.trialata (Passiflora) & CFEM & - & nt & $\mathrm{nt}$ & $+(\mathrm{A})$ \\
\hline *P.tripartita (Tacsonia) & EG, CFEM & EG & nt & nt & $+(\mathrm{A})$ \\
\hline P.vespertilio (Decaloba) & - & EG & nt & EG & - \\
\hline
\end{tabular}

EG: embryo germination; CFE: callus formation from endosperm; CFEM callus formation from embryo; -: no response; nt: not tested; * tissue culture not previously reported. ${ }^{a}+$ : plant regeneration was obtained under the conditions described in the results from material induced in the medium indicated in parentheses.

The following species did not respond to any of the tested media: P.actinia (Passiflora), P.adenopoda (Decaloba), P.ambigua (Passiflora), P.amoena (Astrophea), P.aurantia (Decaloba), P.boenderi (Decaloba), P.cinnabarina (Decaloba), P.cuneata (Decaloba), P.edulis flavicarpa (Passiflora), P.elegans (Passiflora), P.fanchonae (Decaloba), P.gabrielliana (Passiflora), P.gibertii (Passiflora), P.guatemalensis (Decaloba), P.hahnii (Decaloba), P.lancetillensis (Deidamioides), P.laurifolia (Passiflora), P.ligularis (Passiflora), P.lutea (Decaloba), P. maliformis (Passiflora), P.manicata (Manicata), P.menispermifolia (Passiflora), P.mixta (Tacsonia), P.murucuja (Murucuja), P.pergrandis (Passiflora), P.pittieri (Astrophea), P.quadrangularis (Passiflora), P.serratifolia (Passiflora), P.serratodigitata (Passiflora), P.serrulata (Passiflora), P.suberosa (Decaloba).

set of undifferentiated cell proliferation, especially from cotyledon edges and hypocotyl, which resulted in callus production.

Embryo germination occurred at a higher frequency on medium B (17 of 20 responsive species), while medium A ordinarily induced embryos to produce undifferentiated calli (17 of 18 responsive species), as expected
(Ko et al., 1983). However, 7 of the 27 responsive species presented embryo germination in medium A, while 8 of the 27 responsive species presented calli on medium B. In particular, P. kawensis responded only to medium A with embryo germination.

In the case of accidental wounding during seed opening, isolated embryo organs were still able to grow, 


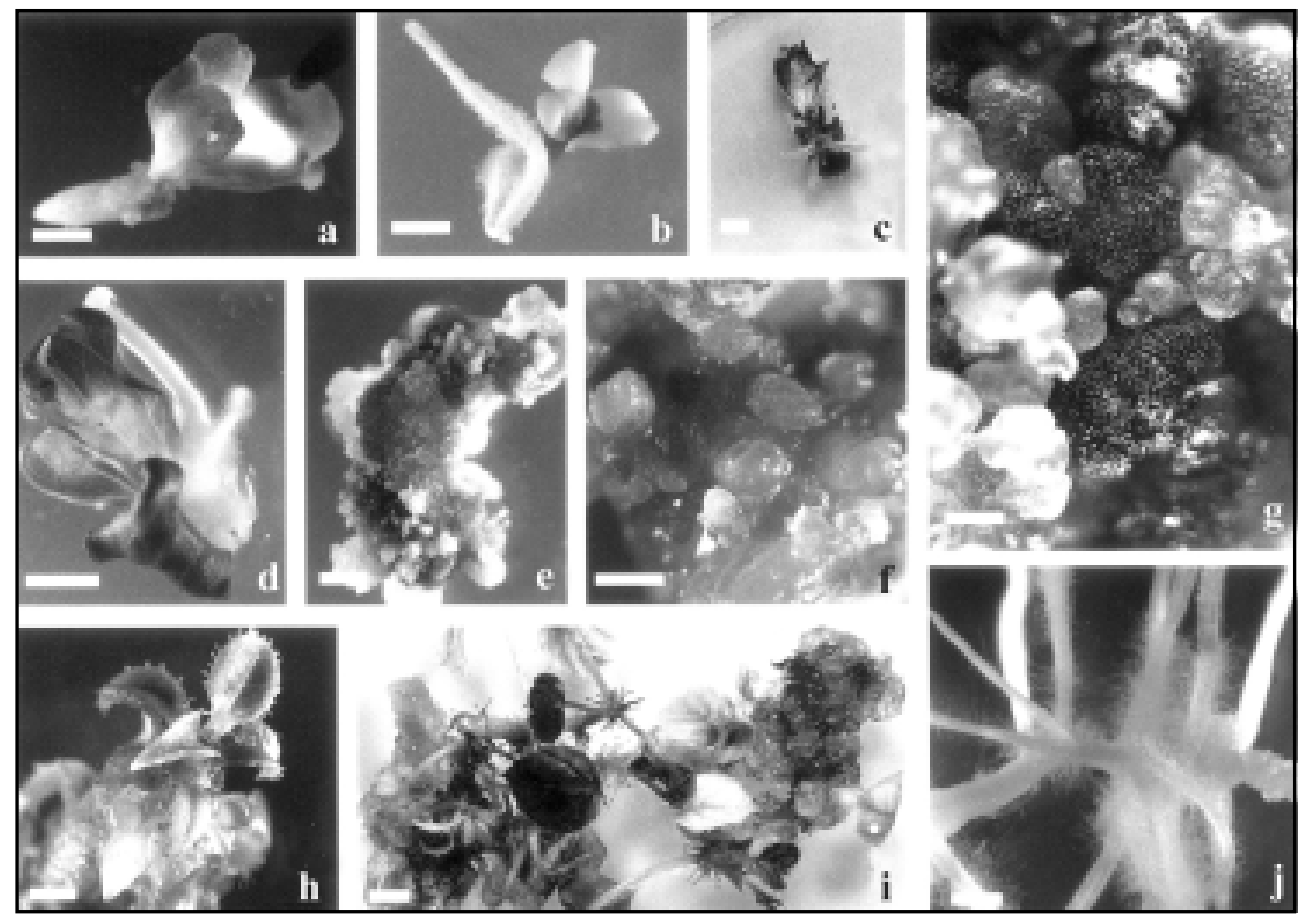

Figure 1 - In vitro culture of Passiflora embryos. Embryos in vitro germinated from a) P. trialata and b) P. incarnata, c) P. foetida: shoot germination in an embryo with partially coated root, d) $P$. cincinnata: isolated embryo shoot, with root induced on IBA containing medium, e) $P$. garkei: green, compact callus, f) P. trialata: green compact callus transferred to REM showing early regeneration response, g) $P$. garkei: green compact callus transferred to REM, showing the development of organized masses with epidermislike purple layers. Well-developed shoots from regenerating calli of h) P. palmeri and i) P. foetida, j) P. mayarum branched roots emerging from white friable callus in callus maintaining B5+ medium. Bar a-e, h-j $=500 \mu \mathrm{m} ; \mathrm{f}, \mathrm{g}=100 \mu \mathrm{m}$.

giving rise to shoots without roots and vice-versa (data not shown). Shoots grew independently from the root even in the case of incomplete excision of the embryo from seed coats, when residual seed coat pieces embedded the root (Figure 1c). It is reasonable to surmise that the failure of root germination depended on some dormancy factors within the seed coats that were still in tight contact with the root. The independent shoots were able to root on medium containing IBA (indole-3-butyric acid) (RM, see Table 1) (Figure 1d); the independent roots were cut and used to obtain calli in high 2.4D (2.4-dichlorophenoxyacetic acid) medium (B5-2, Table 1).

Fragments of endosperm from mature seeds were also explanted in A, B, and BG media, resulting in undifferentiated white or yellow callus production for 7 of the 27 species in A, 2 of the 27 species in B, and 1 of the 4 species in BG (Table 2). Several species did not respond to any of the tested media (Table 2). However, for some unresponsive species only a very few seeds were available. The responsiveness of species to our culture conditions appeared to be independent on the taxonomic position, at least for the Decaloba and Passiflora subgenera, in which 8 of 19 and 12 of 27 species, respectively, showed some kind of response.

\section{Callus culture and plant regeneration}

Undifferentiated calli were spontaneously produced especially from embryos grown on medium A. Alternatively, pieces of embryo-derived hypocotyl or root were cut and transferred to high 2.4-D (B5-2 medium, Table 1) to obtain calli. Different embryos from a single species and even individual embryos produced calli with different characteristics (Table 3).

These calli were separated and grown on B5 medium containing $2.25 \mu \mathrm{mol} \mathrm{L}{ }^{-1} 2.4-\mathrm{D}$ and several homogeneous cell lines with different features were obtained (Table 3). Media with high 2.4-D ( $\left.9 \mu \mathrm{mol} \mathrm{L}^{-1}\right)$ were chosen for species with very high morphogenetic capabilities, such as $P$. foetida, in order to maintain the undifferentiated callus.

Preliminary characterization has shown that calli have different morphogenetic potential, even within the same species. The growth rate of calli varied greatly among different species. The increase in weight of very low and fast growing species are detailed in Table 4. Green and compact calli were chosen as the best candidates to induce shoot regeneration (Figure 1e). For this purpose, calli were treated with medium containing 6BAP (6-benzylaminopurine) (REM, Table 1). Regeneration was obtained after a transition period varying from 
Table 3 - Characteristics of calli obtained from Passiflora responsive species

\begin{tabular}{|c|c|}
\hline Specie & Characteristics of calli \\
\hline P.apetala & $c-d \quad c-y \quad f-y$ \\
\hline P.auriculata & $c-y \quad c-g \quad f-y$ \\
\hline P.candida & $c-d$ \\
\hline P.cincinnata & c-d $\quad c-g \quad c y$ \\
\hline P.cirrhiflora & $\begin{array}{cccc}c-g & c-y & f-y & f-w\end{array}$ \\
\hline P.coccinea & $c-g$ cy $f-g$ f-y $f-w$ \\
\hline P.coriacea & $c-d \quad c-g \quad f-w \quad f-d$ \\
\hline P.crenata & $c-g$ \\
\hline P.foetida & $c-d \quad c-g \quad c-y \quad f-g \quad f-y$ \\
\hline P.garckei & $\begin{array}{lll}c-g & f-g & f-y\end{array}$ \\
\hline P.glandulosa & $c-w \quad c-d$ \\
\hline P.hahnii & $\mathrm{c}-\mathrm{d}$ \\
\hline P.incarnata & $c-y \quad c-g$ \\
\hline P.incarnata "alba" & $f-y \quad f-g$ \\
\hline P.kawensis & $f-w$ \\
\hline P.mayarum & $\mathrm{c}-\mathrm{g}$ \\
\hline P.morifolia & $f-w \quad c-g$ \\
\hline P.nitida & $\begin{array}{llll}c-g & f-g & f-y & f w\end{array}$ \\
\hline P.palmeri & $c-g \quad c-d \quad f-g \quad f-y \quad f-w$ \\
\hline P.platyloba & $f-w$ \\
\hline P.rufa & $c-g \quad c-d \quad c-y \quad f-y \quad f-w$ \\
\hline P.sicyoides & $c-d$ \\
\hline P.subpeltata & $\mathrm{c}-\mathrm{w}$ \\
\hline P.subrotunda & $c-d$ \\
\hline P.tenuifila & $c-d \quad f-d \quad f-y \quad f-w$ \\
\hline P.trialata & $c-g \quad c-d \quad f-g \quad f-w$ \\
\hline P.tripartita & $c-g \quad c-w$ \\
\hline P.vespertilio & $c-w \quad f-w$ \\
\hline
\end{tabular}

c: compact; f: friable; y: yellow; g: green; w: white d: dark yellow.

a few weeks to several months. During this period, green round masses that gradually developed an epidermis-like tissue appeared at the callus surface (Figures 1f, g). Successively, shoots emerged from these masses (Figure $1 \mathrm{~h}$, i). Shoot regeneration was successful in 13 callus-forming species. Calli of $P$. foetida and P. tenuifila developed shoots spontaneously even without 6-BAP treatment.

Shoot regeneration was accompanied or followed by root regeneration in either MS hormone-free or IBA containing medium (RM, Table 1$)$. In only one case $(P$. palmeri) the shoots did barely differentiate into roots, even in rooting medium and over a long period of time (several months).

In callus-maintaining medium, $P$. mayarum had spontaneous formation of long and branched roots from white friable calli (Figure. 1j). These roots were subsequently able to develop shoots in hormone-free medium. Calli obtained from endosperm have not yet been tested
Table 4 - Weight (g) increase of selected Passiflora calli after 20 days of culture

\begin{tabular}{lccr}
\hline $\begin{array}{l}\text { Species (type of } \\
\text { callus) }\end{array}$ & $\begin{array}{c}\text { initial weight } \\
(\mathrm{t} 0)\end{array}$ & $\begin{array}{c}\text { final weight } \\
(\mathrm{t} 20)\end{array}$ & $\mathrm{t} 20 / \mathrm{t} 0^{\mathrm{a}}$ \\
\hline$P$. rufa $(\mathrm{c}-\mathrm{g})$ & 0.578 & 1.980 & 3.43 \\
$P$. apetala $(\mathrm{f}-\mathrm{w})$ & 0.254 & 0.611 & 2.41 \\
$P$. nitida $(\mathrm{f}-\mathrm{y})$ & 0.260 & 3.962 & 15.24 \\
$P$. garkei $(\mathrm{f}-\mathrm{y})$ & 0.298 & 3.850 & 12.92 \\
$P$. palmeri $(\mathrm{f}-\mathrm{y})$ & 0.293 & 4.394 & 14.99 \\
\hline
\end{tabular}

${ }^{a}$ ratio between final and initial weight.

$P$. rufa and P. apetala are representative of low-growing species, while P. nitida, P. garkei and P. palmeri are representative of fast growing species.

for their regeneration capabilities. However, regeneration from endosperm-derived callus has been described in $P$. foetida (Mohamed et al., 1996).

\section{Plantlet acclimatization}

Plantlets obtained from embryo germination or by regeneration were acclimatized and transplanted into pots and grown in the greenhouse, with a near $100 \%$ success rate, with the exception of $P$. vespertilio. In the greenhouse, mature plants of $P$. foetida, P. tenuifila and $P$. coriacea appeared to be fertile, spontaneously producing seed-containing fruits. P. apetala and P. palmeri produced normal flowers, although no fruits have yet been observed. Since plants were not hand-pollinated, this could simply be attributed to the absence of the proper pollinator in self-incompatible species. The other species have not reached sexual maturity yet.

In conclusion, embryo culture allowed the production of calli from 29 Passiflora species, and plant regeneration from 13 of these. For 25 of the responsive species, tissue culture had not been previously reported. Embryo culture represents a possible strategy to obtain Passiflora plants not only to provide a continuous source of material, but also for the conservation of endangered species.

\section{ACKNOWLEDGEMENTS}

To Dr. Maurizio Dalla Vecchia for the gift of Passiflora seeds and to Leica Microsystems for providing us access to a stereomicroscope and a digital camera. This research was supported by the University of Verona.

\section{REFERENCES}

ANTHONY, P.; OTONY, W.; POWER J.B.; LOWE K.C.; DAVEY M.R. Protoplasts isolation, culture, and plant regeneration from Passiflora. Methods in Molecular Biology, v.111, p.169-181, 1999.

DORNELAS, M.C.; VIEIRA, M.L.C. Plant regeneration from protoplast cultures of Passiflora edulis var. flavicarpa Deg., P. amethystina Mikan and P. cincinnata Mast. Plant Cell Reports, v.13, p.103-106, 1993.

DORNELAS, M.C.; VIEIRA, M.L.C. Tissue culture studies on species of Passiflora. Plant Cell Tissue and Organ Culture, v.36, p.211-217, 1994. 
DORNELAS, M.C.; TAVARES, F.C.A.; DE OLIVIERA, J.C.; VIEIRA, M.L.C. Plant regeneration from protoplast fusion in Passiflora spp. Plant Cell Reports, v.15, p.106-110, 1995.

FARIA, J.L.C.; SEGURA, J. In vitro control of adventitious bud differentiation by inorganic medium components and silver thiosulfate in explants of Passiflora edulis f. flavicarpa. In vitro Cellular \& Developmental Biology-Plant, v.33, p.209-212, 1997.

FEUILLET, C.; MAC DOUGAL, J.M. Passiflora trialata (Passifloraceae), a new species of Granadilla (Passiflora subg. Passiflora) from French Guiana. Novon, v.6, p.351-355, 1996.

GAMBORG, O.L.; MILLER, R.A.; OJIMA, K. Nutrient requirements of suspensions cultures of soybean root cells. Experimental Cell Research, v.50, p.151-158, 1968.

KAWATA, K.; USHIDA, C.; KAWAI, F.; KANAMORI M.; KURIYAMA A. Micropropagation of passion fruit from subcultured multiple shoot primordia. Journal of Plant Physiology, v.147, p.281-284, 1995.

KO, S.W.; WONG, C.K.; WOO, S.C. A simplified method of embryo culture in Oryza sativa L. Botanical Bulletin of Academia Sinica, v.24, p.97101, 1983.

MOHAMED, M.E.; HICKS, R.G.T.; BLAKESLEY, D. Shoot regeneration from mature endosperm of Passiflora foetida. Plant Cell Tissue and Organ Culture, v.46, p.161-164, 1996
MONTEIRO, A.C.; NAKAZAWA, G.T.; MENDES, B.M.; RODRIGUEZ, A.P. In vitro regeneration of Passiflora suberosa leaf disks. Scientia Agricola, v.57, p.571-573; 2000.

MURASHIGE, T.; SKOOG, F. A revised medium for rapid growth and bioassays with tobacco tissue cultures. Physiologia Plantarum, v.15, p.473-497, 1962.

OTONI, W.C.; CASALI V.W.D.; CECON, P.R.; DAVEY M.R.; POWER, J.B. Plant regeneration from leaf mesophyll-derived protoplasts of Passiflora coccinea. Revista Ceres, v.42, p.461-468, 1995.

VAZ D'UTRA, F.D.; DOS SANTOS, A.V.P.; MANDERS, G.; COCKING, E.C.; DAVEY, M.R.; POWER, J.B. Plant regeneration from leaf mesophyll protoplasts of the tropical woody plant passionfruit (Passiflora edulis fv flavicarpa Degener): the importance of the antibiotic cefotaxime in the culture medium. Plant Cell Reports, v.12, p.220-225, 1993.

Received March 13, 2003

Accepted October 29, 2003 